\title{
Perception of Malaysian Society Toward Existence of Indonesian Workers in Malaysia
}

\author{
Siska Widyawati ${ }^{1}$ and Sumaiyah Binti Muhd Radzi ${ }^{2}$ \\ 1) Graduate Student of Geography Education, Universitas Negeri Padang, Indonesia \\ e-mail: Siskawidyawati555@gmail.com \\ 2) Student of Geography, Malaya University, Malaysia \\ e-mail: sumaiyahr96@gmail.com
}

*Corresponding Author, Received: September 14, 2018, Revised: October 21, 2018, Accepted: December 05, 2018

\begin{abstract}
The purpose of this research was to find out how the perception of Malaysian society towards Indonesian Workers (TKI) in Malaysia. This research is descriptively intended to describe carefully the particular social phenomena that are being studied by developing concepts and gathering facts by using observation, interview and documentation studies in data collection. The types of data used are primary data and secondary data obtained from Indonesian workers in Malaysia. Primary data is collected by interviewing resource persons and conducting observations or open observations related to the perception of the Malaysian public towards Indonesian migrant workers. The subject of this study is that the Malaysians themselves can provide their views or perceptions of migrant workers, not limited to their social status. The analysis results of this study include 1) Protection and Legal Status of Indonesian Migrant Workers in Malaysia, 2) The Influence of Indonesian Migrant Workers on the availability of employment in Malaysia, 3) Interaction between Indonesian labor migrants and Malaysian society,4) Problems faced by Indonesian labor migrants in Malaysia.
\end{abstract}

Keywords: Indonesian Workers, Labor Migrant

\section{Introduction}

Population problems are an important problem in the world, especially for developing countries, including Indonesia (Hermon, 2016a; Hermon, 2017; Hermon et al., 2018a). One of the population problems is rapid population growth (Hermon, 2010a; Hermon, 2012a; Hermon, 2015a). This will cause problems in meeting their needs because the growth of primary needs is not balanced with population growth (Sumatmadja, 1981 in Iswandi 2010). In line with population growth, there is an increase in the needs of life, both in quantity and quality (Hermon, 2010b). According to BPS data, the number of poor people in Indonesia in 2007 reached 37,168,300 people (16.58\%), in 2008 it reached 34,963,300 people (15.42\%), in 2009 it reached $32.530,000$ people $(14.15 \%)$, and in 2010 it reached 31,023.400 people (13.33\%). The government has attempted with various programs rolled out to reduce poverty in Indonesia, since the monetary crisis that occurred in early July 1997 which turned into an economic crisis two years later resulted in a collapse of economic activity because many companies had to close and the number of unemployed workers increased. When we talk about employment availability we will discuss unemployment rates in urban areas and those in rural areas (Hermon, 2009; Hermon, 2010b). The unemployment rate in Indonesia from the onset of the monetary crisis in early July 1997 to 2010 has increased. In life in the current era of globalization, the level of economic growth of the community is required to always be able to meet the needs 
of each individual who is expensive and different with a high level of need, as human cultural beings have needs. Needs are all that humans need to perfect their lives (Abdulkadir, 2006; Hermon, 2012b). At present, the population growth has been very high and the addition of the population is always accompanied by an increase in various necessities of life such as settlements, agriculture, etc. (Iswandi and Berlian 2010; Hermon, 2014a; Hermon, 2014b; Hermon, 2014c). On the basis of reason, encourage every individual to get a lot of money in a fast way, one of which is to become an Indonesian Worker. Indonesian Workers hereinafter referred to as Indonesian Migrant Workers are every Indonesian citizen who fulfils the requirements to work abroad in a working relationship for a certain period of time by receiving wages (Pringgo, 2015). According to Article 1 section (1) of Law Number 39 of 2004 concerning the Placement and Protection of Indonesian Migrant Workers Abroad, Indonesian Migrant Workers are every Indonesian citizen who is eligible to work abroad in an employment relationship for a certain period of time by receiving a wage. Whereas according to the guidance book for Indonesian labor services companies are Indonesian citizens both men and women who carry out activities in the fields of economy, social, scientific, arts and professional sports as well as attending job training abroad both on land, sea and air within a period certain based on the work agreement that is an agreement between the worker and the employer verbally and or written both for a certain time and for an indefinite period which contains the terms of employment, rights and obligations of the parties. Work is a basic need for all humanity to fulfil their needs in life. According to Eka (2012); Hermon (2015b); Hermon (2016b); Hermon (2016c); Hermon et al., (2017), this employment function serves as a vehicle to place humans in a central position in development. Employment is a source of income for the workforce who work. The amount or amount of income derived from employment determines the prosperity of a family. In Indonesia the right to get a job is the right guaranteed by the constitution, this is regulated in Article 27 paragraph 2 of the 1945 Constitution which reads "Every citizen has the right to work and livelihood that is appropriate for humanity." logical consequences that the Indonesian state must fulfil the rights of its citizens including to fulfil the need for work for every citizen who is willing and able to work (Adnan, 2006; Hermon et al., 2018b; Hermon et al., 2018c). Fulfilment of employment independently by the Indonesian state is very difficult to achieve if we look at the comparison between the high level of unemployment and the availability of jobs in Indonesia today.

The issues above include are factors of Indonesian worker migrating to abroad. Supriana and Nasution (2010) stated that this driving factor came from domestic migrant workers. It is simply explained that the driving factor for this is in the economic angle, namely the situation of excess supply of the domestic labor market. Meanwhile, the Indonesian worker's situation tends to be high in the level of open unemployment and weak absorption in the formal sector. Likewise, many jobs in the informal sector are characterized by low income. This reality causes workers to find alternative work abroad. It was added that the attracting factors originating and abroad in the form of higher wages are complementary to rounding up the motivation of the choice. In the end, the Indonesian worker program abroad could not be avoided anymore. Apart from that Arif (1998) Explains the differences in demographic conditions, culture and development models that are applied to make socio-economic progress achieved by each country vary greatly, in fact, these differences have encouraged residents to leave their home countries in search of a better life in the country others, which certainly have a higher economic rating than their home countries. According to Asmara et al (2017); Oktorie (2017); Oktorie (2018); Kristian and Oktorie (2018), related to the theory of Economic Human Capital. This theory assumes that the movement of an individual to another place is to obtain greater income, this action is considered as an act of investing in human resources. For this reason, it is clear that people will migrate to places that have higher wages or salaries to meet the needs of life so as to increase their social mobility in the community.

Therefore, the government has set it in a clear regulation contained in the Law of the Republic of Indonesia No. 39 of 2004 concerning the Placement and Protection of Indonesian Workers Abroad. The law also stipulates the procedure for placement of Indonesian migrant workers, which includes the placement of Indonesian worker migrants according to their interests and talents, as well as the technical aspects of administrative services. During this time, it also regulates the use of migrant workers abroad so that there is clarity of work and protection.

Based on factors and experience can change people's perceptions of how to become migrant workers. According to Irwanto et al (1997) defines perception as the process of receiving stimuli (objects, quality, relationships between symptoms, and events) until the stimulus is realized and understood, in this case the 
strong impression of working abroad is easier, relatively high wages, the story of the success of Indonesian worker migrants overseas has shaped the public perception that working abroad will change fate and life more successfully than work in the country. While the opposite impression as the problem of Indonesian migrant workers seems to disappear by this positive impression. Based on the above background, the formulation of the problem in this study is what and how the perception of the Malaysian people towards Indonesian worker choose to work in Malaysia.

\section{Method}

Type of this research is descriptive (Hermon et al., 2008). According to Sugiyono (2012) in Rayendra (2017), descriptive research is research that seeks to describe and interpret data with objective measurements of existing phenomena. In this study intended to describe carefully the particular social phenomena being investigated by developing concepts and collecting facts about the perception of the Malaysian people towards Indonesian workers migrants by using observation, interview and documentation study techniques in data collection. The types of data used are primary data and secondary data obtained from Indonesian workers in Malaysia. Primary data is collected by interviewing informants and conducting observations or open observations related to the perception of the Malaysian community towards Indonesian labor migrants. The subject of this study is that Malaysian society is not limited in terms of social status.

\section{Results and Discussion}

\section{Protection and Legal Status of Malaysia against Indonesian Migrant Workers}

Indonesia continues to strive to carry out national development in the context of the development of a whole Indonesian people in order to realize a prosperous, just and prosperous society that is equally material and spiritually based on the Pancasila and the 1945 Constitution of the Republic of Indonesia. In national development, labor has a role and a very important position as the subject of development.

Protection of workers/workers is an inseparable part of the protection of citizens as a state obligation. Basic rights as humans must be fulfilled by getting protection where they work to get their basic rights. Both the different status of their citizens and the same status as their country, so they get a decent life as a human being in accordance with Article 28 D Paragraph 3 of the 1945 Constitution of the Republic of Indonesia, that: "Every citizen has the right to work and get fair and decent compensation and treatment in a working relationship. "The rampant cases of ill-treatment of Indonesian Workers (hereinafter abbreviated as Indonesian Migrant Workers) who work abroad, leaving a melancholy for their families, relatives and relatives. Therefore, workers need legal protection and human rights which are basic rights that are inherent and protected by the constitution as stipulated in article 27 paragraph (2) of the basic laws of the Republic of Indonesia in 1945 which reads "Every citizen entitled to work and livelihoods that are suitable for humanity ", and Article 33 paragraph (1) which states that" The economy is structured as a joint effort on family. "Therefore, violations of basic rights protected by the constitution constitute human rights violations.

Protection of workers is intended to guarantee the basic rights of workers and guarantee equal opportunities and treatment without discrimination of any kind to realize the welfare of workers and their families while paying attention to the development of business progress and the interests of employers. Legislation related to the protection of workers, namely Law No. 13 of 2003 concerning employment and implementing regulations of legislation in the field of labor.

As it is known that Indonesian workers who work in Indonesia, are mostly concentrated in Malaysia as the most importing country of labor originating from Indonesia. Therefore, the protection of labor through a joint agreement between the Indonesian As it is known that Indonesian workers who work in Indonesia, are mostly concentrated in Malaysia as the most importing country of labor originating from Indonesia. Therefore, the protection of labor through a joint agreement between the Indonesian government and Malaysia in the form of a Memorandum of Understanding (MoU) is needed by both countries, especially Indonesia to provide legal protection for Indonesian workers who work in Malaysia. Protection of the basic rights of Indonesian migrant workers in Malaysia has been established by the government. 
The form of protection previously agreed upon by Indonesia and Malaysia is by making an agreement in the form of a formal TOR Memorandum of Understanding (MoU), namely Indonesian migrant workers who work in the mining, agriculture and factory sectors then a Memorandum of Understanding Therefore, the protection of labor through a joint agreement between the Indonesian government and Malaysia in the form of a Memorandum of Understanding. (MoU) is needed by both countries, especially Indonesia to provide legal protection for Indonesian workers who work in Malaysia.

Protection of workers is intended to guarantee the basic rights of workers and guarantee equal opportunities and treatment without discrimination of any kind to realize the welfare of workers and their families while paying attention to the development of business progress and the interests of employers. Legislation related to protection for workers, namely Law No. 13 of 2003 concerning employment and implementing regulations of legislation in the field of employment As it is known that Indonesian workers who work in Indonesia, are mostly concentrated in Malaysia as the most importing country of labor originating from Indonesia. Therefore, the protection of labor through a joint agreement between the Indonesian government and Malaysia in the form of a Memorandum of Understanding (MoU) is needed by both countries, especially Indonesia to provide legal protection for Indonesian workers who work in Malaysia. Protection of the basic rights of Indonesian migrant workers in Malaysia has been established by the government. The form of protection that had previously been agreed upon by Indonesia and Malaysia was by making an agreement in the form of a formal TOR Memorandum of Understanding (MoU), namely Indonesian working in the mining, agriculture and factory sectors then a Memorandum of Understanding.

A large number of immigration problems of Indonesian Workers abroad, not only creates legal problems for those concerned but can also lead to bad precedents for the Government of Indonesia. Because of that, various efforts have been made by the Republic of Indonesia Government, in order to eliminate these bad potentials, including the provision of TKI / Prospective Indonesian Migrant Workers with immigration material as well as the rights and obligations of Indonesian migrant workers.

The rights and obligations of Indonesian Migrant Workers were conveyed by the Head of the Malaysian Manpower Office, during the Seminar on the Socialization of the Malaysian Manpower Regulations and the Immigration Regulations of Malaysia, according to the Work Deed of 1955. The deed included: Right to get prior notice of termination of employment, time of payment of salary, amount of deductions allowable salary, payment method required by the bank, leave rights, working hours and overtime regulations. In addition, it was also conveyed related to the compensation rules for workers based on the Worker's Pamphlet Act 1952.

The deed aims to ensure that workers who get disasters receive reasonable compensation, as long as they do not work or experience disabilities due to work accidents. The deed also aims to ensure that the person covered by the deceased worker (heir) receives compensation if death occurs while working. Compensation will be paid to workers who experience calamity at work.

In addition to the agreement between Indonesia and Malaysia, concerning the protection and legal status of Indonesian workers relating to human rights enforcement, the most interesting thing is that the Malaysian government also pays close attention to the education of the children of Indonesian labor migrants so that they also have the right to continue. education and there are also among children who are given the opportunity to compete for educational scholarships provided by the Malaysian government. in addition to education, the health of Indonesian migrant workers is treated equally with indigenous people.

\section{The Influence of Indonesian Migrant Workers on Malaysian Community Employment Opportunities.}

Indonesian worker is an important factor in the production process in addition to land, capital and others because humans are the drivers of all these factors of production. The term employment opportunities mean employment or opportunities available to work as a result of an economic activity (production). Thus the notion of employment opportunities includes the field of work that has been filled and all jobs that are still vacant. From the vacant employment (which means there is an opportunity), then the need for labor arises. Manpower needs are obviously needed by companies/institutions to accept labor at the level

certain wages, positions and terms of employment. Employment opportunity data is difficult to obtain, so for practical purposes, an approach is used that the number of employment opportunities is 
approached through the number of jobs that have been filled by labor. Job opportunities are the number of people can be absorbed to work in a company or an agency, this employment opportunity will accommodate all available labor if the available employment is sufficient or balanced with a large number of available labor (Tambunan, 2001). According to Worker official, 2000, employment opportunities are the number of people who can be absorbed to work for a company or agency. Job opportunities are generally defined as a condition that reflects the amount of the total workforce that can be absorbed or actively participate in economic activities. The need for labor is based on the idea that labor in society is one of the potential factors for overall economic development, thus the large population of Indonesia can determine the acceleration of the rate of economic growth. Job opportunities available and the quality of labor used will determine the economic development process to carry out the production process and also as a market for goods and services.

The purpose of using Indonesian worker migrants in Malaysia is to meet the needs of skilled and professional workers in certain fields that cannot be occupied by local workers as well as stages in accelerating the national and regional development processes because these workers can indirectly assist in the growth of the Malaysian economy. So it can be concluded that the presence of these migrant workers can fill the workforce needs in Malaysia, including as domestic workers, cleaning service, refinery workers, traders, and some are involved in matters of government such as education personnel.

\section{The interaction between Indonesian worker migrants and Malaysian worker}

According to Shaw (2010) where social interaction is an interpersonal exchange, each person shows their behaviour to each other. The same thing also stated by Thibaut and Kelley (2008) that social interaction as an event affects each other when two or more people are present together, they create a result for each other or communicate with each other. So in the case of interaction, everyone's actions aim to influence other individuals. Forms of social interaction can be in the form of cooperation (cooperation), competition (competition) and can even be in the form of conflict or conflict. Charles H. Cooley (in Soekanto, 2006) says how important cooperation is, and cooperation arises when there is an awareness that the person has the same interests and at the same time has enough knowledge and education for himself to fulfil the interests that. Social interaction is a package of social reality with special characteristics namely: the number of actors of two or more people, communication between actors using symbols or symbols, the process will occur in a certain time dimension, and there are goals to be achieved.

The results showed that Indonesian labor migrants who worked in Malaysia gave a positive response from the Malaysians themselves, this was related to the interaction that was born by Indonesian labor migrants, the labor migrants quickly mingled with the Malaysian community, were friendly, polite and few of them gave birth to a bad image of migrant workers Even worker seem to be very hard-working, when compared to other foreign workers, sometimes if their working hours are excessive they will also ask for more wages too, meaning that in this case the service of Indonesian migrant workers in Malaysia can be said to be pretty good. The good communication between Malaysia and Indonesia is very good, this is because Indonesian and Malaysian languages are a language family, namely Malay so that the communication runs smoothly, we know that language is the main communication tool for an interaction between individuals or groups.

\section{Problems faced by Indonesian labor migrants in Malaysia}

The social problem is basically an unwanted condition of life in society or a living condition that causes problems. Social problems can occur due to obstacles in meeting needs, due to socio-economic changes and the use of science and technology. It can even occur due to reasons that are difficult to predict in advance such as natural disasters. As an undesirable condition or cause problems, it is natural that then people try to carry out repairs or problem-solving. According to Parrilo $(1987 ; 14)$ to understand social problems need to understand the four components, namely: (1) the problem persists for a period of time, (2) it can cause various physical or mental damage to both individuals and society, (3) is a violation of social values or standards of a community or several joints of life and (4) create a need for a solution 
In order to be able to do social problem solving a step is needed to understand the symptoms and understand the process and background of the occurrence of these symptoms. Some labor problems such as limited expertise, lack of opportunity to get a job in the country, income that is far greater than working in the country, or the desire to improve the standard of economic life should not be underestimated without consideration of the readiness of Indonesian workers who will work in Malaysia. From the observations, it is shown that the problems faced by Indonesian labor migrants originating from within the country are, among other things, the falsification of the identity of Indonesian migrant workers, the skills and skills of Indonesian labor migrants who are not in accordance with the qualifications of their work, lack of language skills. So that most of the migrant workers work as domestic servants (PRT), cleaning service, labor and others related to the type of abusive labor, so that the views of the indigenous people (Malaysia), that labor migrants are the same as domestic workers, while according to the company's supervision manual Indonesian labor services are both male and female Indonesian citizens who carry out activities in the economic, social, scientific, arts and professional sports fields and attend job training abroad both on land, sea and air within a certain period of time.

From the results of the study, there are three immigration violations that are often encountered, namely: 1) No documents/passports, 2) overstay, and 3) non-permitting work/misuse of residence permits. Foreigners who enter/stay without documents are subject to a fine of no more than RM10,000, or imprisonment of no more than 5 years, or both. Overstay faces a fine of no less (minimum) RM10,000 or imprisonment of no more than 5 years, or both. Misuse of the permit, threatened with a fine of not more than RM1,000 and/or imprisonment of no more than 6 months. Malaysians who employ undocumented foreigners face a prison sentence of not more than 12 months, and or a fine of not less than RM10,000 and not more than RM50,000. if employing more than 1 Illegal worker, the user is threatened with a sentence of not less than RM10,000 and not more than RM.50,000 / worker and/or imprisonment of at least 6 months and a maximum of 5 years.

\section{Conclusion}

From the results of this research we can the conclusion that: First, the protection of workers/workers is an inseparable part of the protection of citizens as state obligations. Basic rights as human beings must be fulfilled by getting protection wherever they work to get their basic rights. Secondly, Indonesian labor migrants in Malaysia can meet the needs of skilled and professional workforce in certain fields that can not be occupied by local workers as well as stages in accelerating the national and regional development processes, because these workers can indirectly assist in the growth of the Malaysian economy. So it can be concluded that the presence of these migrant workers can fill the workforce needs in Malaysia, including as domestic workers, cleaning service, refinery workers, traders, and some are involved in matters of government such as education personnel. Third, Indonesian migrant workers who work in Malaysia have given a positive response from the Malaysians themselves. This is related to the interactions that are born by Indonesian labor migrants, the Indonesian labor migrants quickly mingle with Malaysian society, are friendly, polite and few of them give birth to a bad image of Indonesian migrant workers. Fourth, some labor problems such as limited expertise, lack of opportunity to get a job in the country, income that is far greater than working in the country, or the desire to improve the standard of economic life should not be underestimated without consideration of the readiness of Indonesian workers who will work in Malaysia.

\section{References}

Abdulkadir, M. 2006. Etika Profesi Hukum, PT Citra Aditya Bakti. Bandung.

Arif, N. 1998. Mobilitas Tenaga Kerja Indonesia Ke Luar Negeri dan Dampaknya Terhadap Diri Migran : Suatu Tinjauan Awal terhadap Kasus Buruh Bangunan di Kuala Lumpuur. Fakultas Isipol, Universitas Sumatera Utara.

Asmara, R and Pierewan. 2017. Mobilitas Sosial Tenaga Kerja Indonesia (TKI) Ponorogo (Studi Kasus Pada Masyarakat Kelurahan Keniten Kecamatan Ponorogo Kabupaten Ponorogo). Jurnal Pendidika Sosiologi. Fakultas Ilmu Sosial Universitas Negeri Yogyakarta. Vol 1, No 2 (24-25) 
Adnan, H. 2006. Perlindungan dan Hak Tenaga Kerja Indonesia yang Bekerja di Luar Negeri : Harapan dan Tantangan, Themis, No 1 Vol 1 Tahun 2006, hal 78, makalah di akses dari www.univpancasila.ac.id pada tanggal 14 februari 2012.

Eka, R. P. 2012. Pengaruh Nilai Investasi, Nilai Upah, dan Nilai Produksi Terhadap Penyerapan Tenaga Kerja Pada Industri Mebel di Kecamatan Pedurungan Kota Semarang. Economics Development Analysis Journal.Fakultas Ekonomi, Universitas Negeri Semarang, Indonesia, Vol 1, No 2.

Hermon, D., Khairani., Daswirman., S. Karim., Dasrizal., and Triyatno. 2008. Metode dan Teknik Penelitian Geografi Tanah: Aplikasi Instrumen dan Acuan Penelitian Geografi Fisik. Yayasan Jihadul Khair Center.

Hermon, D. 2009. Dinamika Permukiman dan Arahan Kebijakan Pengembangan Permukiman pada Kawasan Rawan Longsor di Kota Padang. Disertasi. IPB Bogor.

Hermon, D. 2010a. Geografi Lingkungan: Perubahan Lingkungan Global. UNP Press.

Hermon, D. 2010b. Arahan Kebijakan Pengembangan Permukiman pada Kawasan Rawan Longsor di Kota Padang. Jurnal SKALA. Vol. 1.

Hermon, D. 2012a. Mitigasi Bencana Hidrometeorlogi: Banjir, Longsor, Degradasi Lahan, Ekologi, Kekeringan, dan Puting Beliung. UNP Press. Padang.

Hermon, D. 2012b. Dinamika Cadangan Karbon Akibat Perubahan Tutupan Lahan Permukiman di Kota Padang Sumatera Barat. Forum Geografi: Indonesian Juornal of Spatial and Regional Analysis. Volume 26. Issue 1. p: 45-52. Uniiversitas Muhammadiyah Surakarta.

Hermon, D. 2012c. Analisis Erodibilitas Tanah dengan Metode Bouyoucos untuk Arahan Pertanian Konservasi Ideal dalam Pembangunan Berkelanjutan. Jurnal Pelangi. Vol. 2 Issue. 2.

Hermon, D. 2014a. Arahan Mitigasi Bencana Longsor Kawasan Gunung Padang Kota Padang Sumatera Barat. Jurnal Geografi. Volume 9.

Hermon, D. 2014b. Impacts of Land Cover Change on Climate Trend in Padang Indonesia. Indonesian Journal of Geography. Volume 46. Issue 2. p: 138-142. Fakultas Geografi Universitas Gajah Mada.

Hermon, D. 2014c. Desain Kebijakan Tanggap Darurat dan Pemulihan Bencana Letusan Gunung Sinabung. Seminar Nasional Geografi. Master Program of Geography Education, Universitas Negeri Padang.

Hermon, D. 2015a. Geografi Bencana Alam. Jakarta: PT RajaGrafindo Persada.

Hermon, D. 2015b. Arahan Kebijakan Keberlanjutan Pendidikan 10 Tahun Pasca Bencana Tsunami di Kabupaten Aceh Jaya Provinsi Aceh. Seminar Nasional Geografi. Master Program of Geography Education, Universitas Negeri Padang.

Hermon, D. 2016a. Mitigasi Perubahan Iklim. Rajawali Pers (Radjagrafindo).

Hermon, D. 2016b. Estimate of Changes in Carbon Stocks Based on Land Cover Changes in the Leuser Ecosystem Area (LEA) Indonesia. Forum Geografi. Volume 29. Issue 2. p: 188-196.

Hermon, D. 2016c. The Change of Carbon Stocks and CO2 Emission as the Result of Land Cover Change for Tin Mining and Settlement in Belitung Island Indonesia.Journal of Geography and Earth Science. Volume 4. Issue 1. p: 17-30.

Hermon, D. 2017. Climate Change Mitigation. Rajawali Pers (Radjagrafindo).

Hermon, D., P. Iskarni., O. Oktorie and R. Wilis. 2017. The Model of Land Cover Change into Settlement Area and Tin Mining and its Affecting Factors in Belitung Island, Indonesia. Journal of Environment and Earth Science. Volume 7 No. 6. p: 32-39. IISTE.

Hermon, D., Ganefri., A. Putra and O. Oktorie. 2018a. The Model of Mangrove Land Cover Change for the Estimation of Blue Carbon Stock Change in Belitung Island-Indonesia. International Journal of Applied Environmental Sciences. Volume 13. Issue 2. p: 191-202. Research India Publication.

Hermon, D., Y. Suasti., Ernawati., Afdhal., and H. Edial. 2018b. Geografi: Geografi untuk SMU. Jurusan Geografi Universitas Negeri Padang. 
Hermon, D., A. Putra., and O. Oktorie. 2018c. Suitability Evaluation of Space Utilization Based on Enviromental Sustainability at The Coastal Area of Bungus Bay in Padang City, Indonesia. International Journal of GEOMATE. Volume 14. Issue 41. p: 193-202. Geomate International Society.

Irwanto. 1997. Psikologi Umum : Buku Panduan Mahasiswa. Jakarta : Gramedia Pustaka.

Iswandi and Bakaruddin. 2010. Analisis Konversi Lahan Persawahan Dan Dampaknya Terhadap Lingkungan di Kota Padang. Laporan Penelitian Dosen Muda, Direktorat Jenderal Pendidikan Tinggi Kementrian Pendjdikan Nasional Jurusan Geografi Fakultas Ilmu-Ilmu Sosial Universitas Negeri Padang.

Iswandi and E.Berlian. 2010. Kajian Degradasi Lahan Di Kota Padang Kecamatan Pauh, Lubuk Kilangan, Dan Kuranji). Laporan Penelitian Dosen Muda, Direktorat Jenderal Pendidikan Tinggi Kementrian Pendjdikan Nasional Jurusan Geografi Fakultas Ilmu-Ilmu Sosial Universitas Negeri Padang.

Kristian, A and O. Oktorie. 2018. Study of Coastal Mangrove Conservation in the World. Sumatra Journal of Disaster, Geography and Geography Education. Volume 2. Issue 1. p: 49-52

Oktorie, O. 2017. A Study of Landslide Areas Mitigation and Adaptation in Palupuah Subdistrict, Agam Regency, West Sumatra Province, Indonesia. Sumatra Journal of Disaster, Geography and Geography Education. Volume 1. Issue. 1. p: 43-49. Master Program of Geography Education.

Oktorie, O. 2018. Model Kebijakan Responsif Pemulihan Bencana Letusan Gunung Sinabung. Jurnal Kapita Selekta Geografi. Volume 1. Issue 1. p: 15-20

Parrillo, V. N et al. 1987. Comtemporary Social Problems.John Wiley \& Sons.New york.

Pringgo, S. S. 2015. Perlindungan Tenaga Kerja Indonesia Di Luar Negeri. Jurnal Ilmiah. Program Studi Magister Ilmu Hubungan Internasional Pasca Sarjana Universitas Muhammadiyah Yogyakarta.

Rayendra, M. 2017. Halal Tourism Development in East Lombok Regency. Sumatra Journal of Disaster, Geography and Geography Education, Facultyof Social Science, Universitas Negeri Padang, Indonesia.Vol1, No.2 (197-201).

Shaw. 2010. Psikologi Sosial. Bandung : Rosdakarya

Supriana, T dan Nasution, V. L. 2010. Peran Usaha TKI Purna terhadap Pengembangan Ekonomi Lokal dan Faktor yang Mempengaruhi Pendapatan Usaha TKI Purna di Provinsi Sumatera Selatan.Makara : Jurnal Sosial Humaniora. Vol. 14, No. 1, hal. 4250.

Tambunan, T. 2001. Transformasi Ekonomi di Indonesia. Jakarta: SalembaEmpat.

Thibaut dan Kelley. 2008. Teori Sosiologis Edisi Enam.Jakarta : Rineka Cipta

Soerjono, S. 2006. Sosiologi Suatu Pengantar. Jakarta : Raja Grafindo Persada. 